\title{
Cross-Generation Perceptions of the Samin Tribe towards Management Behavior Environmental
}

\author{
Rahseta Abdika Syaifullah $^{1}$, Muhamad Ganang Rindarjono ${ }^{2}$, Puguh Karyanto ${ }^{3}$ \\ \{rahseta@student.uns.ac.id ${ }^{1}$ \} \\ ${ }^{1,2,3}$ Postgraduate at Universitas Sebelas Maret, Surakarta, Indonesia
}

\begin{abstract}
As a tribe that still has a nature dependency, no doubt the samin tribe have their own procedures in managing the environment. This study was intend to determine the management behavior enviromental of the Samin Tribe based on perceptions obtained from the old generation and the response of the young generation of Samin Tribe to the management behavior environmental of the old generation of Samin Tribes. This research was using qualitative methods. The amount of attitude or management behavior environmental in Samin Tribe which obtained from primary data then it was quantified in tabulation form through the Microsoft Excel Program to look the frequency of percentage data from interview result, observation and secondary data later analyzed in descriptively. Analyze result of the old generation in managing environment got a positive response from the Samin's young generation, it is proven by 12 respondents in average 9 said "good" and 3 said "good enough".
\end{abstract}

Keywords: Management behavior environmental, Perception, Samin Tribe

\section{INTRODUCTION}

The environment as a unity of space with all objects, power, circumstances, and living things, including humans and their behaviors that affects the surrounding environment, the life survival and the welfare of humans and other living beings. The environment provides many benefits to human life. In terms of the economy, the environment provides a source of food, land for housing and businesses, as well as industrial raw material, whereas in terms of social, environmental provide means to socialize and develop culture.

The attitude, behavior and Human Adaptation to the majority is determined by its perception. In the process of perception, individuals are required to provide an assessment of an object which can be positive, negative, and so on. The attitude is formed by the existence of perception, which tend to be stable to apply or act in a certain specific situation in anyway. So the link between the actions of members of the public towards environmental management. When individual societies have a positive perception about how to manage the environment, then the action will be positive as well. In contrast, when members of the society have a negative perception, then the action will then tend to damage or detriment to environmental sustainability, [1]. Public Perceptions and Support of Environmental Management in the 
SourceArea of Drinking Water for Beijing China, Local people from the watershed of Miyun Reservoir werefound to pay little attention to the environmental situation of the downstream reservoir, [2]. The managerial perceptions about the characteristics of the environment influence the extent to which firm managers are proactive regarding environmental issues, [3]. Environmental perception of solid waste management in the municipalities of Patzcuaro Mexico, although it is a low income and low education level area the majority of the inhabitants ownstheir own homes. It was revealing to find that the fraction of the population that does not believe that solid waste is causing any problem at the community is similar to the fraction that burns and/or uses open dumps. [4]

In this study based on the aim to know the behavior of the older generation of Samin's tribe environmental management and the perception of the younger generation against the behavior of the older generation Samin's tribe environmental management, then the research is expected to deliver input to the Samin's society and local government to increase understanding about the importance of safe guarding the environment especially in water, energy and waste management, to create the management of environmentally environment that provides the benefits of ecologically and economically for the Samin's people of Klopodhuwur Village, Blora City.

\section{METHOD}

This study uses qualitative methods. Data sources derived from primary data and secondary data obtained through the techniques of data collection in the form of observation, interview, semi structured, survey and study of literature.

This research was carried out in Karangpace, Klopodhuwur, Banjarejo, Blora Regency, Central Java. The choice of location is based on the residence of the Samin's tribe who adhere to the teachings of the Samin's tribe.

The materials used in this research is stationery, cameras, recording devices, a detailed questionnaire, GIS software, and spatial maps of Central Java from BIG.

In this study, the term population and sample were changed to social situations and informants / participants / resource persons. Social situations consist of three elements, namely: places, actors, and activities that interact synergistically. The social situation can be expressed as the object of research that wants to know about what happened in it, [5]. The selection of informants in this study used a purposive sampling method. Purposive sampling is a sampling technique of data sources with certain considerations. The sample size in purposive sampling is determined by consideration of the information provided, if the determination of the sample unit (informant) has reached the level of redundancy (saturated data, plus the informant no longer provides new information), then the sampling is stopped, this shows that the determination of sample units is considered adequate. for this study, 35 informants were made up of 23 from the older generation and 12 from the younger generation of samin, in which there were tribal chiefs, village officials, and samin tribal people.

The value of behavioral attitudes of environmental management obtained from the interviews of 23 respondents / informants from the old generation of Samin's tribes and perceptions of the younger generation amounted to 12 respondents / informants as primary data and will be quantified in the form of tabulations through the Excel's program, to find the frequency and percentage of interview results semi structured, then analyzed descriptively. 


\section{RESULT}

In addition to the development process that often resulted in environmental degradation, consumer behavior and lifestyles of humans also resulted in environmental problems. Based on the results of Intergovernmental Panel on Climate Change (IPCC) in 2007, in addition to natural factors, human activity is also a major cause of the increasing concentration of greenhouse gases in the Earth's atmosphere, which in turn contribute the onset of global warming and climate change. Some human activities include water use, energy use, waste processing.[6]

\subsection{Environmental Management's Behavior of Samin's Tribe (the Older Generation) 3.1.1 Water Management of Samin's Tribe}

The availability of water resources in earth are limited. $71 \%$ of the Earth's surface is water, but only about $2.5 \%$ is fresh water while the rest is sea water containing salt. Only about $1 \%$ which can be utilized by humans directly or about $30 \%$ of total supplies of fresh water. A very limited water availability that requires the utilization of water in an efficient and prudent.

\section{a. The Availability Of Water Facilities}

The existence of water sources in the area of residence of the population/households marked with the water facilities such as the presence of wells, water pump, tap, or water channelfrom springs that channelled to home. The percentage of Samin's households that have water facilities for drinking/cooking/bathing/washing are $100 \%$. This results came from the perception of Samin's older generation, who says that the source of this water is given by the Government to managed by Samin's.

\section{b. Source Of Drinking Water}

Households as one of the water users urgently needs water everyday for various purposes, especially for drinking. Percentage of Samin's households according to the main water source used for drinking purposes, $100 \%$ of Samin's society using clean water for drinking needs.

\section{c. Water Use Behavior WhileWashing}

The use of water-saving behavior can also be made when washing clothes, cutlery, or fruit and vegetables. The way to wash using water containers in a relatively efficient because of the volume of water used would be more controlled than using water flowing from the pipes/hoses. How Samin's societies using water while washing we can see on the chart below. 
Graphic 3.1.Samin's societies using water while washing

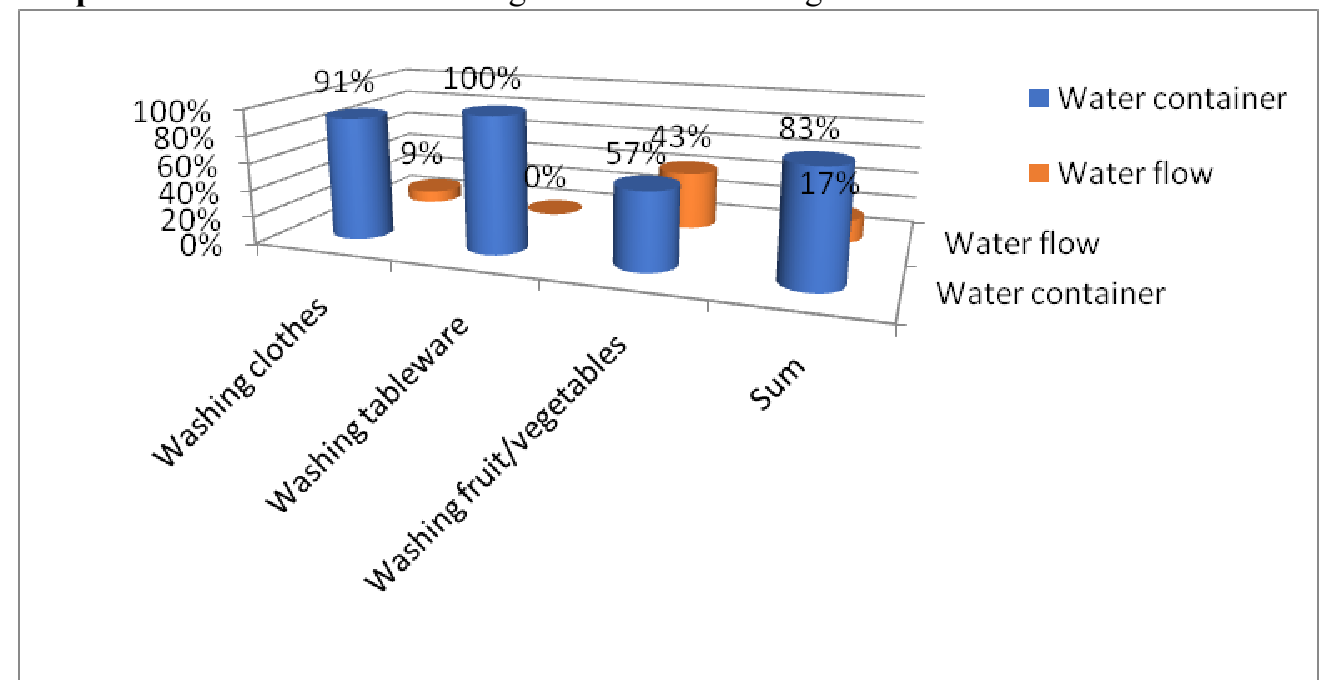

From the chart above can be explained that the behavior of the use of water when washing clothes in Samin's society is $91 \%$ use water container and, $9 \%$ use flowing water, the behavior of the use of water when washing the cutlery is $100 \%$ with water container, the behavior of the use of water when washing fruit and vegetable $57 \%$ by water container and $43 \%$ by flowing water. This proves that Samin's society are efficient while using water for washing.

\section{d. The Existence Of Water Absorption Area}

Water absorption area has function as a shelter and retaining rain water either through the roof or directly into the ground, so that rain water does not instantly lost to the water ways, but seep back into the ground as a source of clean water. Percentage of households that have a water absorption according to the type of area is $100 \%$ from forests absorption, rice paddies $\&$ grasslands. This proves that Samin's society close to nature and plants, as Lasiyo, indigenous elders saying that "the master of plants is human, including anything that grow from the Earth are brothers and sisters, groomed and not groomed whose life in the grounds including grass leaves, mountain, stone, fleas-lice, locusts and other all brothers, so don't take the origin before asking permission".

\subsubsection{Management of Energy in Samin's Society}

\section{a. The Utilization Of Sunlight}

The sun shines all years in Indonesia with a very numerous intensity. The utilization of the sunlight on the households can be done through utilization of sunlight for drying clothes and crops during the day. It is very helpful for Samin's society because the majority of society worked as farmers so that crops such as rice and corn can be dried up and crops can be processed further. Percentage of utilization of the sunlight for drying clothes in Samin's community is $100 \%$ and the utilization of the sunlight for drying crops of rice and corn $94 \%$ and people who are not utilize for drying crops $6 \%$ because they didn’t work as farmers. 


\section{b. Habit of Using Electronic Tools}

Unconsciously, our sensitivity in the use of electric energy can be seen from the custom in diverse electronic equipment at house. Knowledge will build sensitivity, and the sensitivity will be create a characters. For example turning on the television, the habit of letting the television turned on although it is not being watche dare mistakes in the reduction of the efficiency of the electricity consumption.

Graphic3.2 Samin's Habit when Letting Television Turned On.

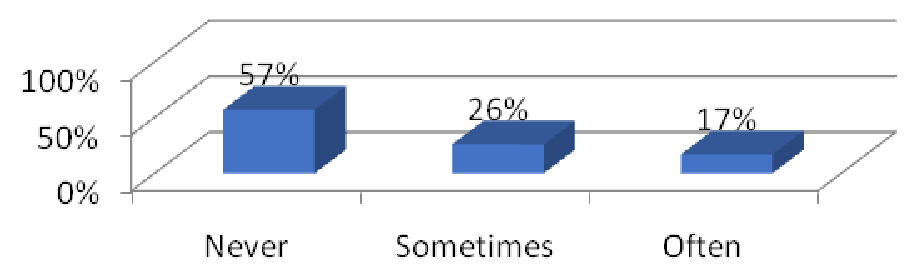

The habit of letting the television remains lit even though not on the watch $57 \%$ never letting the television remainlit, sometimes letting the television remainlit about $26 \%$ and $17 \%$ often let the television remain lit while not on watch.

\subsubsection{Waste Management}

Along with the increase of population and the increasing activity of the population, then the amount of trash generated each day also increases, thus increasing the number of bins must be accompanied by a good waste management and the engine that started from a household scale, where households are a source of waste producers.

\section{a. The Habit Of Disposing Garbage}

The habit of disposing waste in the household can be categorized in two ways, namely dump with an eco-friendly way and dispose of garbage in a way not environmentally friendly. The ways to disposing garbage according to Samin's society is $100 \%$ burned by fire.

\section{b. Behavior Towards Junk Worth Using}

Used items worth sharing as second hand thrift, shoes, tools, etc. for some people regarded as junk and just thrown away without being exploited again. Percentage of the society's behavior toward thrift deserves to wear is $68 \%$ utilized for other purposes, $23 \%$ are given to everyone else, $9 \%$ are sold.

\subsection{Perceptions of Samin's Young Generation Tribe}

In the process of perception, individuals are required to provide an assessment of an object which can be positive or negative [17]. The attitude is formed by the existence of perception, which tend to be stable to apply or act in a certain specific situation in anyway. Such is the case with the Samin'syounger generation's perception of how society's response to the environmental behavior of Samin's society. If the individual has a positive perception of 
the younger generation against the behavior of the Samin's older generation tribe environmental management, it will have a positive opinion, so did the opposite.

Table3.1. Perceptions of Samin's Young Generation Tribe

\begin{tabular}{|c|c|c|c|c|}
\hline \multirow[b]{2}{*}{ No } & \multirow{2}{*}{$\begin{array}{c}\text { Perceptions of } \\
\text { Samin's Young } \\
\text { Generation } \\
\text { Tribe }\end{array}$} & \multicolumn{3}{|c|}{ Environmental Management Behavior in Samin's Society } \\
\hline & & $\begin{array}{l}\text { Water } \\
\text { Management }\end{array}$ & $\begin{array}{l}\text { Energi } \\
\text { Management }\end{array}$ & $\begin{array}{l}\text { Waste } \\
\text { Management }\end{array}$ \\
\hline 1. & Good & 12 & 7 & 9 \\
\hline 2. & Good Enough & & 5 & 3 \\
\hline 3. & Less Good & & & \\
\hline 4. & Not Good & & & \\
\hline 5. & Sum & 12 & 12 & 12 \\
\hline
\end{tabular}

Nearly all of the younger generation say that environmental management behavior in Samin's society right now is a form of Samin's description it self, the results of the interview said that in management of water amounted to 12 respondents said "good", energy management of 7 respondents said "good" and 5 respondents said "Good enough", waste management of 9 respondents said "good" and 3 respondents said "good enough".

\section{CONCLUSION}

Environmental Management Behavior In Samin's Society Based On Samin's Older Generation Water management: 1Water availability of Samin's society is $100 \%$ for daily needs. 2The source of drinking water availability of Samin's society is $100 \%$ get/use a clean source of water for drinking. 3Behavior use of water when washing is $82 \%$ of the society responded well when washing clothes, dinner ware and vegetable/fruit hold water using container in order to save water usage. 4Water absorption area availability arround the residence is $100 \%$, Samin's society have water absorption area due to the settlement of the tribe near the forests and rice fields.

Management of energy: 1The utilization of sunshine is $100 \%$, Samin's tribe utilize it for drying clothes and $94 \%$ is used for drying rice and corn because most societal worked as a farmer. 2Behavior of using electronic tools was 57\%, Samin's society answered "never" to let the television remain illuminated while not watch able, $26 \%$ answered "sometimes", and 17\% responded "often". This proves that the Samin's society still categorized as well-saving in the use of electronic tools. Waste management: 1Custom dump of Samin's society is $100 \%$ directly burning trash into fire without sorted first, and this can cause air pollution and the most severe effects of rising greenhouse gases. 2Behavior toward junk worth using, $68 \%$ are used for other purposes, $23 \%$ are given to everyone else, and $9 \%$ are sold, it is concluded that in the conduct of the use of used goods worth sharing between Samin's society still utilized well. The perception of the Samin's younger generation about environmental management behavior in Samin'stribe is positive, it proves by 12 respondents/informant, about 9 respondents says "good" and 3 said "good enough".

\section{REFERENCE}

[1] D. Novalanty, O. Daulay, and J. W. Hidayat, "Persepsi Masyarakat terhadap Pengelolaan Taman Nasional Batang Gadis , Kabupaten Mandailing Natal , Provinsi 
Sumatera Utara Communities Perceptions to Batang Gadis National Park Management, Mandailing Natal Regency, North Sumatera Province," vol. 14, pp. 233-240, 2016.

[2] X. Wang, Q. Feng, Y. Zhang, S. Duan, and V. Novotny, "Public Perceptions and Support of Environmental Management in the Source Area of Drinking Water for Beijing, China," Environ. Eng. Res., vol. 15, no. 1, pp. 49-56, 2010.

[3] M. D. López-Gamero, E. Claver-Cortés, and J. F. Molina-Azorín, "Environmental perception, management, and competitive opportunity in Spanish hotels," Cornell Hosp. Q., vol. 52, no. 4, pp. 480-500, 2011.

[4] O. Buenrostro, L. Márquez, and S. Ojeda, "Environmental perception of solid waste management in the municipalities of PÁtzcuaro region, Mexico," Environ. Eng. Manag. $J .$, vol. 13, no. 12, pp. 3097-3103, 2014.

[5] Sugiyono, Metode Penelitian Kuantitatif, Kualitatif dan R\&D. Bandung: Alfabeta, 2014.

[6] BPS, Indikator Perilaku Peduli Lingkungan Hidup 2014 Perilaku Peduli, vol. 2014. 2014.

[7] S. Road and U. Kingdom, "Durham Research Online Use policy," World, vol. 44, no. April, pp. 0-32, 2009.

[8] R. ALMEIDA, L. M. SCATENA, and M. S. DA LUZ, "Environmental Perception and Public Policies - Dichotomy and Challenges To the Development of a Sustainability Culture," Ambient. Soc., vol. 20, no. 1, pp. 43-64, 2017.

[9] L. Nurrani and S. Tabba, "Persepsi dan Tingkat Ketergantungan Masyarakat Terhadap Sumberdaya Alam Taman Nasional Aketajawe Lolobata di Provinsi Maluku Utara (Communities Perception and Reliances on Natural Resources of Aketajawe Lolobata National Park in North Maluku Province)," J. Penelit. Sos. dan Ekon. PKehutanan, vol. 10, no. 1, pp. 61-73, 2013.

[10] F. G. Vodouhê, O. Coulibaly, A. Adégbidi, and B. Sinsin, "Community perception of biodiversity conservation within protected areas in Benin," For. Policy Econ., vol. 12, no. 7, pp. 505-512, 2010.

[11] H. Nanlohy, A. N. Bambang, A. Ambaryanto, and S. Hutabarat, "Analisis Persepsi Masyarakat terhadap Pengelolaan Kawasan Mangrove Teluk Kotania," J. Wil. dan Lingkung., vol. 2, no. 1, p. 89, 2016.

[12] W. H. Suryaningsih, H. Purnaweni, and M. Izzati, "Persepsi dan perilaku masyarakat dalam upaya pelestarian hutan rakyat di Desa Karangrejo Kecamatan Loano Kabupaten Purworejo," Ekosains, vol. IV, no. 3, pp. 27-38, 2012.

[13] Y. Chaesfa and N. K. Pandjaitan, "Persepsi Perempuan Terhadap Lingkungan Hidup dan Partisipasinya dalam Pengelolaan Sampah Rumahtangga," J. Sosiol. Pedesaan, vol. 1, no. 2, pp. 165-181, 2013.

[14] D. Rajapaksa, M. Islam, and S. Managi, "Pro-environmental behavior: The role of public perception in infrastructure and the social factors for sustainable development," Sustain., vol. 10, no. 4, 2018.

[15] R. A. Budiman, Z. Saam, and Thamrin, "Partisipasi dan Persepsi Masyarakat Dalam Upaya Menjaga Mengelola Lingkungan Hidup dan Mempertahankan Predikat Kota Bersih,” J. Ilmu Lingkung. ISSN 1978-5283, vol. 7, no. 2, pp. 103-113, 2013.

[16] P. Watson, “of Science," vol. 355, no. 6326, 2017.

[17] K. Saddhono, "Language of Coastal Communities in the Northern Coast of Central Java: Sociolinguistic Studies in Cultural Integration Maritime-Agrarian Perspective." Adv. Sci. Let. vol. 23 no. 10 pp 10054-10056, 2017 
